\title{
Innovative Techniques in the Context of Actions for Flood Risk Management: A Review
}

\author{
Maria Martinez $^{1, *(D)}$, Ramez Bakheet ${ }^{2}$ (D) and Shatirah Akib ${ }^{3, *(D)}$ \\ 1 School of Science, Engineering and Design, Teesside University, Middlesbrough, Tees Valley TS1 3BX, UK \\ 2 Inertia Construction, Giza 12588, Egypt; Ramez.gsh@yahoo.com \\ 3 Department of Civil Engineering, School of Architecture, Design and the Built Environment, \\ Nottingham Trent University, Nottingham NG1 4FQ, UK \\ * Correspondence: mariaolivamartinezmorillo@gmail.com (M.M.); shatirah.akib@ntu.ac.uk (S.A.)
}

\section{check for}

updates

Citation: Martinez, M.; Bakheet, R.; Akib, S. Innovative Techniques in the Context of Actions for Flood Risk Management: A Review. Eng 2021, 2, 111. https://dx.doi.org/10.3390/ eng2010001

Received: 3 November 2020 Accepted: 21 December 2020 Published: 23 December 2020

Publisher's Note: MDPI stays neutral with regard to jurisdictional claims in published maps and institutional affiliations.

Copyright: () 2020 by the authors. Licensee MDPI, Basel, Switzerland. This article is an open access article distributed under the terms and conditions of the Creative Commons Attribution (CC BY) license (https: / / creativecommons.org/ licenses/by/4.0/).

\begin{abstract}
The general purpose of this review paper is to provide an overview of various flood protection strategies because flooding is becoming more frequent and is affecting more areas, displacing people, and increasing fatalities around the world. The concern surrounding climate change resulting in sea level rise, increasingly frequent storm events, and the need for adaptive actions to better control urban storm water runoff motivates the completion of this paper. Understanding the impact of climate change aside from dangerous weather conditions essential for designing effective mitigation strategies, but first, there needs to be a clear and strong understanding of the effects of extreme events. This review represents engineered storm water practices that are adaptive, in combination with the non-structural measures such as urban planning, will help reduce flood impact.
\end{abstract}

Keywords: flood risk management; flooding; structural measures; non-structural measures; flood solutions; flood innovations

\section{Introduction}

Climate change has significantly affected the probability of flooding [1] due to the rise in sea levels worldwide due to a billion tons of ice melted every year (sea levels are rising about $3 \mathrm{~mm}$ a year), which threatens many coastal cities to be partially or totally underwater between 2030 and 2040 [2,3]. An increase in precipitation extremes are one of the clearest features of climate change. In our mid-latitudes, extratropical cyclones that come from oceanic storm tracks are the main source of rainfall for Europe and North America. These phenomena generate many of the precipitation extremes associated with flooding and major losses. The challenge in predicting the future behaviour of regional storm tracks is derived from the several processes that control the regional locations of the storm tracks and their varied response to related aspects of global warming such as equator-to-pole temperature gradients, sea-ice decrease, patterns of sea-surface temperature (SST), and land-sea temperature contrasts $[4,5]$. Moreover, climate change could concentrate the hydrological cycle, which will cause more intense rainfall, leading to increased frequency and severity floods [6] (e.g., in the UK, the rainfall in 2015 broke all records, receiving $341 \mathrm{~mm}$ within one day, breaking the 2009 record of $316.4 \mathrm{~mm}$ ). Floods not only lead to structural damage in infrastructure (roads, sewage treatment plant, and energy supplies), but also to economic losses, for example, the UK spent 1.3 billion every year to treat the effects of flood damage [7]. Researchers have also observed a significant local and global increase in the proportion of the strongest hurricanes (Categories 4 and 5) associated with a huge amount of rainfall. Studies attribute the increase in global heating of the climate, and this increase in the most powerful storms happened in conjunction with a similar decrease in Category 1 and Category 2 hurricanes [8,9]. Other studies have also reported the change in the seasonality of intense rains, where now these events can happen during any season of the year and not only the rainy seasons, as was usual in past decades [10]. Therefore, it is 
very important to predict the occurrence of floods to minimize the risk of flooding and its potential impacts. To predict floods, several data should be available such as precipitation data on a real-time basis, the rate of change in the river stage, the type of storm (duration, intensity, and areal extent), and knowledge about the characteristics of a river's drainage basin. These data are strengthened by technology, as wireless electronic sensors and neural network computer models could help to predict floods more accurately [11,12]. Flooding is increasing in recent times due to climate change and it is necessary to know the annual flood increment rate for particular countries [13]. Low-income societies in areas subjected to a high probability of flood risk are usually more vulnerable to hazard impacts because of the socioeconomic characteristics that make them less able to cope, adjust, or adapt to the hazards. Moreover, the fact that both risk perception and awareness levels are low among this communities indicates that when the next flash flood event occurs, the effectiveness of risk management plans may be limited [14-16]. Mitigation of flood risks includes structural flood measures corresponding to the construction of dams, sea walls (Figure 1), river dikes, and levees, and non-structural measures such as flood estimation, warning, flood hazard, risk management, community involvement, and official planning, etc. [17]. River polders or flood expansion areas are the real pillars in many national flood defence programs [18-20]. Polders have been installed as flood control and waterlogging drainage systems in the low-lying areas of the plain river network at Yangcheng and Dianmao. It was proven that with the expansion of the polder areas and increased standard of flood control and waterlogging drainage in polder areas, the water level in the main river increases drastically under the same flood, which contributes to the major impact on flood control in the area [21]. Non-structural measures involve non- physical construction such as the use of knowledge, practice, or agreement (laws and policies) to reduce the impacts and risks of flooding, training, education, and raising public awareness. Flood risk management measures may include climate change mitigation, rural runoff reduction and storage, flood incident management, land-use planning and risk spreading (insurance), health and social measures, building codes, and flood-proofing [22]. The purpose of this work was to provide an overview of the structural and non-structural measures of flood mitigation. The correct protection of communities with the most adequate design of structural measures, which consider the consequences of climate change, will allow for the adaptation of the population to flooding. Structural measures are engineering procedures to decrease the vulnerability of defences through the dissipation of energy [23,24]. Adaptive, multifunctional infrastructure in combination with water sensitive urban plan are means in which to strengthen resilience against climate change [25]. The application of plans that contain the facility of flood safety for storms, surge fences, flood barricades, seawalls, anti-backflow regulators, and dikes, in addition to raising the ground floor of houses, the construction of pumping stations, the increase of drainage capacity, the use of fishponds as retaining pools and constructing flood alteration channels, are all potential approaches for flood mitigation $[26,27]$. The combination of structural and non-structural measures can significantly help to fortify the flexibility of communities to the reality of climate change. Non-structural measures use knowledge, preparation, or contract to decrease flood risk, predominantly through guidelines and regulations, land use, insurance, raising community consciousness, training, and instruction [22,28]. Early warning schemes are more tempting for developing countries, and governments can take effective prevention actions that can alleviate the effects of climate alteration [29,30]. Organization of the possibilities that are available to prevent the consequences of flood events is the outcome of the effort made by the flood risk managing strategy. Some non-structural measures are satisfactory for some countries, while other measures are more acceptable for other countries depending on the level of development of the nation. 

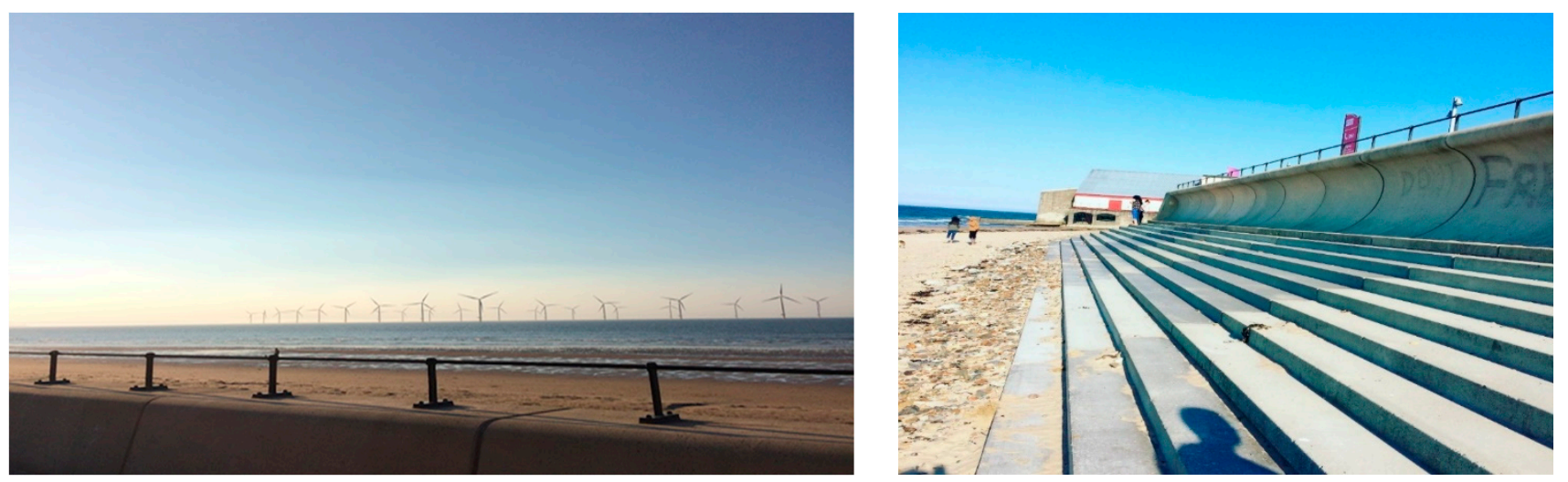

Figure 1. Seawall at Redcar Beach, North Yorkshire, UK.

This review explains how a permeable pavement system represents a solution for the rapid urbanization of cities since the effects of urbanization has led to a significant intensification in impermeable areas. The drainage difficulties for the uncontrolled storm water runoff and flash floods can be reduced by using permeable pavement systems (PPS) [31]. By allowing the infiltration of the water, the pavement can significantly help reduce the risk of flooding.

Flood warning systems offer the real-time prediction of floods, and it is explained in this paper how the influence of the scheme improves the effects in the occurrence of flooding. The flood notice scheme can be sent to other zones of the city to produce arrangements for municipal security, firefighters, circulation regulators, social funding, and additional entities [32]. The presence of flood warning arrangements is an advantage for the community as communication of the event will prevent additional damage to the people nearby.

To reduce the amount of damage produced by flooding, there should be a restriction on the available area for building. Land-living usage arrangement will restrict the creation of structures in the flood plain and will reduce the total damage through time [22]. Preparation for unexpected crisis circumstances must be through land use arrangement and isolated damage decrease (e.g., via creating safety procedures, disaster answers, shielding with water shutters, and building fortifications) [33]. The planning for any event includes the intervention of the community installing protection measures and the use of removable barricades and fortifications to protect themselves from the water action.

\section{Structural Measures}

\subsection{Dams}

Dams require the use of the best design procedure with the purpose of reducing the flooding in specific areas. This procedure should also embrace the intention of finding the best site for the storage facility. The technique used for storage capacity design should determine the site of the storage facility to reduce the costs of flood damage [34]. The use of existing or new dams should also be for the extra determination of flood mitigation, and countries with a wide knowledge in flood control have constructed huge dams with many practical improvements [1]. Dam design has ecological aspects for flood regulation and are built to supply water to communities as well as to reduce flood events.

To reduce the risk of flooding, the design of the dam should consider the consequences of climate change. The design capacity of the dam is affected by future hydrological events as a result of climate change. Flash floods can be alleviated by using protection basins for flood deviation with dams, so dam design has ecological aspects for flood regulation [35]. Supporting structural measures that create room for the water away from urban areas and the impact of changes in the size and location of the dam in combination with the vegetation coverage can reduce peak discharges [36,37]. The rapid development of urban extension in flood prone areas is leading to an increase in flood vulnerability. Including 
urban planning with engineering systems measures will make the alleviation of flood impacts possible.

The focal purpose of the dam design is to use a strategy that reduces the flooding risk in specific areas. Dam safety includes structural, operative, and emergency strategies [38]. Most dam failures and associated fatalities result from flood events. Concrete dams have a low risk of failure compared to embankment dams with a single gated spillway. Large dams are usually well monitored and maintained. A significant level of risk actually comes from small dams (i.e., those local for agriculture), for which the standards for design, construction, surveillance, and maintenance are generally much lower than those of large structures. Although they generally have very small volumes, they can still cause a lot of damage and the risk is quite high. Large dams need to be re-evaluated due to inelastic alterations that occur during a period of strong earthquakes [1]. It is important to check the conditions of large dams to make sure that they are working within the design values, reducing in this way the possibility of catastrophes. Large dams are usually well monitored and maintained. A significant level of risk actually comes from small dams (i.e., those local for agriculture), for which the standards for design, construction, surveillance, and maintenance are generally much lower than those of large structures. Although they generally contain very small volumes, they can still cause a lot of damage and risk is quite high.

\subsection{Dikes}

A dike (or dyke) is a body of rock, either sedimentary or igneous, that cuts across the layers of its surroundings. They form in pre-existing fractures, meaning that dikes are always younger than the body of rock that they have intruded into. Dikes are usually made of earth and used to hold back water. However, dikes can occur naturally and people construct them to prevent flooding. When constructed along river banks, dikes control the flow of water. By preventing flooding, dikes force the river to flow more quickly and with greater force. Figure 2 shows one type of dikes. Risk of dikes should be understood to determine the appropriate risk reduction strategy. Overtopping of the levee is caused by the rise of floodwaters. Levee breaks produced by significant freeboard loss and unintentional overflow certainly denote unsecured levee failure. The execution of emergency measures to indicate unsecured levee sections at high-risk is needed when floodwaters reach the crown of the levee. Levee failures and erosion can be delayed and prevented by using different methods such as the use of filter nonwovens and stabilization measures with geosynthetics. It is impossible for the earthen levee to be eroded and this method could potentially reduce the flood damage $[39,40]$. The vegetation management in flood control structures is an option to improve dike safety and erosion control. Overtopping is a collapse mechanism of the dike with a growth in failure prospect with time and climate [41]. The rise in crest elevation of the current constructions was examined and it was concluded that the essential rise in crest level was around triple that of ocean level rise to preserve the existing allowances. Chen [42] and Savatier [43] also examined how to reduce the overflowing of dikes and concluded that the efficiency of a vegetation management plan that includes safety, landscape, and ecological issues would reduce the criticality of dikes. The peak discharge is reduced with the vegetation coverage and significantly delays the arrival of flood peaks in the environment, which frequently experiences strong rainfall events, often the consequence of storm passage over the zone. Overtopping could be decreased with the increase in crest height and effective vegetation coverage.

\subsection{Flood Barriers}

Reactive response is changing to proactive answer to reduce loss of life and property. Effective strategies like flood barriers are created to be used as dams or seawalls, where they can be made of an elastic or permeable material, the operation could be manual or automatic, and the measurements could be diverse. Flood barriers are pre-installed, demountable, and temporary components that can be at the entry of the buildings or at a certain distance from them. Placing the barriers along a road can guard the zone from the 
water flow during flooding [44]. Flood mitigation using traditional structural measures is operative, but it is also vulnerable to the failure of any of the physical measures with the action of climate change phenomena. Taking in consideration that the construction of any of them is conditioned to the preservation of the environment, the provision of room for the water away from urban areas is vital to guarantee the safety of the community.

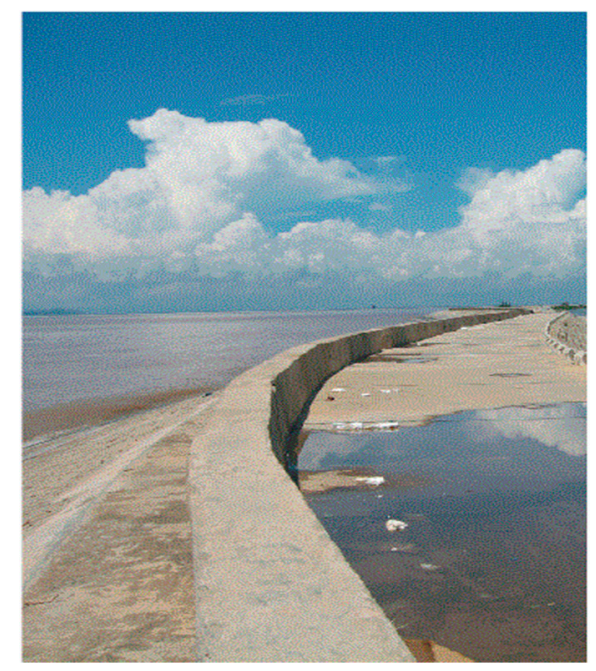

Figure 2. Seawall at Redcar Beach, North Yorkshire, UK.

\subsection{Amphibious Constructions}

Flooding has caused several tragedies in many places around the world and the amphibious house scheme is a new eco-friendly flood mitigation measure. Most European (and not only) flood prone areas are strongly urbanized, often with historical buildings. The feasibility level of the amphibious solution is generally zero. In addition, they devote a lot of space to minor fluid-mechanical problems. Flood adaptation that prevents damage once flooding happens and permits flooding to come into the city is a strategy that anticipates and accommodate flooding. Amphibious constructions are good examples as a solution for flooding. An amphibious foundation keeps a home's association with the ground by resting safely on the ground under ordinary circumstances and permits a house to float in elevation as necessary once flooding takes place because it has a structural frame that attaches to the underneath of the house and supports the flotation foundations [45]. English [46] explained how raising the house exposes the building to significantly stronger winds. Elevated buildings are subjected to greater wind speeds, wind pressure, and forces that may have a significant impact on building damage, but amphibious buildings are a valuable and alternative solution, since the house continues to be close to the ground and only raises the house in the event of dangerous flooding, thus amphibious constructions decrease the susceptibility of flood damage without growing susceptibility to wind destruction.

To determine the exact design force that a flood might exert on an amphibious construction, it is essential to examine the drag coefficient. To design the lateral system of an amphibious house, is necessary to consider the drag force, which acts in the direction opposite to that of the motion of the foundation of the house [47]. The analysis of the stability against vertical and horizontal loads on the amphibious house developed an innovative equation to obtain the drag coefficient [48]. The drag force acts opposite to the motion of the foundation of the house when it is surrounded by water; in other words, it is the force that acts in the opposite direction when the house is floating in elevation once flooding takes place.

Climate change encourages sea level rise and additional dangerous weather actions, so flooding is also expected to become more frequent. English [46] stated that residents 
of flood prone areas would need solutions to address flood impacts, in order to preserve established neighbourhoods and existing architectural character.

\subsection{Permeable Pavement}

Rapid urban development or the impact of urbanization requires the use of permeable pavement systems (PPS), which contribute to alleviating the flooding and minimizing impervious surfaces. As they attenuate storm water flows, dropping, and deferring peak flow rates, PPS is a feasible alternative to old-style schemes [49]. The hydrological performance of a permeable pavement is such that it delays the catchment area response and slow flow velocities, reducing the operating costs of sewer systems and flood risk [50]. PPS is a viable option to unstoppable rapid urbanization as a consequence of the population growing; this flood mitigation is capable of lowering the flood hazard in the community as well as offering safety, allowing the pavement to infiltrate water and at the same time, support the loads of the road traffic.

PPS permits water from precipitation to pass through, decreasing the overflow. In permeable pavements, the hydrological description of water flow relies on the unsaturated hydraulic properties of the construction material, and the excess water can be improved through microbial removal, in addition to purification and sedimentation [51-53]. Highways are susceptible to flooding; Wang [54] provided a method that incorporated flood risk into the structural analysis for flexible pavements. A better pavement design was established, but this analysis was performed on a single-axle load. Porous pavements could help to protect the environment from pollution; their high permeability capacity is very appropriate for some zones vulnerable to substantial rain where rainfall intensity is high.

An effective performance has been shown with the combination of geotextiles and the permeable pavement scheme. Imran et al. [31] focused on drainage systems and storm water runoff from driveways and roads, concluding that permeable pavement systems were effective for storm water management and the use of geotextiles membranes reduced the pollutants from infiltrate run off into the ground. Geotextiles are a versatile instrument that fit into the sustainable urban drainage system approach and can contribute to the ecological defence of the downstream surroundings.

\section{Non-Structural Measures}

\subsection{Urban Design}

The consequences of urbanization are amplified by climate modification, and the expansion of inventive storm water management practices is essential to alleviate these impacts. To alleviate disaster impact, organization and government entities have established frameworks for the assessment and management of flood risks to reduce the negative consequences of flooding on human health, economic activities, the environment and cultural heritage such as the Floods Directive in the European Union, which is a collection of maps for the water information system [55]. Flood adaptation is a strategy that anticipates and accommodates flooding. Cities are required to become more active in focusing on flood response capacity as determined by opportune system wide modification and turning amphibious [56]. All actions required to avoid the consequences of flooding should be considered during the period of planning and design, where alternatives of flood mitigation are recommended for new urbanization.

Rain gardens are appropriate for the management of low flow capacities of rainwater. They are ecological and sustainable, and can be used for storm and flood control. Ellis [57] proposed an integrated catchment management and water sensitive urban design where there is a risk to extensive property flooding, and provided a solution using roadside planters and original basins to obtain a significant reduction in flow. Roadside planters are a type of low-impact development and a good option for the management of storm water runoff to obtain a significant reduction in flow. A conservative approach of treating community flooding is with the construction of sewage schemes, where different methods have to be established in local management plans. 


\subsection{Flood Risk Management Plan}

Integrated flood management plans with targets to reduce the rainfall runoff can provide an effective solution for preventing the inundation of urban areas. It is necessary to study which measures are to be arranged by taking into consideration a good costeffective return. Using regression models, Poussin [58] examined the effect of the flood destruction and also reviewed flood risk prevention plans for communities in flood prone areas. Poussin also took into consideration the flood connexion, flood risk administration strategies, and the social network. Organizational skills are an important aspect in the application of both structural and non-structural flood mitigation practices.

To prevent loss of property and life, it is necessary to create development construction codes, land use strategies, community-based programs, and zoning. Administration plans are essential for any community, and should take into account different experiences, the proportion of risk, the different policies, and the community links. Palencia [59] stated that in Spain, the occurrence of flooding has been traditionally due to their particular conditions, and that one of the most important goals of the United Nations by 2030 for sustainable development is also to drop the number of people affected and the mortality rate by disasters, especially disasters related to flooding. By protecting the poor and vulnerable people around the globe, government agencies should engage with stakeholders to design an effective management plan and improve the financial resilience to flood risk.

\subsection{Land Use}

Land use planning of is one of the essential decisions in flood risk management. It offers various benefits in terms of economic, social, and environmental criteria and so it represents a reasonable solution in lessening the traditional dependence on hydraulic solutions and post-disaster assistance that has historically characterized flood risk management [60]. Cities typically influence land usage patterns by replacing pervious surfaces with impervious ones, thus increasing surface runoff. Miguez [61] and Wagner [62] examined land use and the need to work with nature following urban sustainability. Vulnerable areas that should have been chosen as preservation, recreation or conservation areas were urbanized and overdeveloped due to the pressures of rapid suburbanization and the inappropriate zoning designations.

Damage reducing actions for fluvial flood hazards demonstrate the capacities of land use development, and isolated flood safety procedures. Both are mechanisms of adjustment. The emphasis is essential on the application of these actions as they contribute to a substantial damage decreasing consequence in extreme flood events [39]. The inappropriate zoning designation of an area could cause very destructive consequences by closing natural water paths and also eroding natural defences. In developing new urban areas, land use should be carefully reviewed, in light of the preservation of the environment.

\subsection{Flood Preparedness Measures and Forecasting Warning}

Accurate forecasts of extreme rainfall events are essential for flood prevention due to uncertainties from weather predictions. Some actions are important to prepare for in the case of flooding. Guarding possessions, having shelter, a safe meeting point, early warning systems, emergency preparation, access to flood risk maps, and sharing flood experiences will alleviate the adverse impacts of flood occurrence. Atreya [63] and Ravazzani [64] designed two forecast schemes to manage uncertainties in the boundary conditions, and Gilbuena [65] revealed that the lack of a precise flood predicting system and the absence of appropriate conservation of the flood-warning organization, contributed to flooding. Hsu [66] created a model for more efficiently predicting floods and the modelling approach offered 2-3 h of advanced warning. Amengual [67] provided an enhanced model of forecasting and an early warning procedure and Azam [68] developed an early flood warning scheme to send early flood notice communications about possibly impacted zones. Having an efficient forecast system in combination with communication in advance of 
any flood occurrence, combined with an awareness of the actions that need to be taken individually, is essential to minimize damage and prevent loss of life.

\section{Further Research Needs}

The use of amphibious houses in flood prone areas, in combination with PPS, which can be used as a stable, porous, and permeable pavement in car parks, pedestrian paths, cycle paths, and permeable drives, is a solution that takes the implementation of the available and latest resources from the scientific investigations to alleviate the flooding problem.

In this context, in addition to studies needed on non-structural actions for flood control, the following research gaps have been identified for further research on structural flood alleviation:

- It is necessary to study the association of two spillways as they may increase the flood mitigation.

- There is a need to investigate how many dams need seismic enhancements.

- Further investigation is required on the performance of the measures on earthen dikes as they are very sensitive to erosion.

- It is important to study flood barriers to investigate if automatic flood barrier simulations will provide the same behaviour as manual flood barriers.

- Additional research for flood hazards in relation with flood magnitude and frequency needs to be analysed.

- Permeable pavement systems need new investigations regarding the interactions between axle types and flooded pavement structure, with the consideration of the permanent deformation of the unbound layers.

- Further studies are needed to demonstrate the sustainability of pavement systems, for example, the act of filter media into sumps incorporated at the lowest part of the PPS.

- It is very important to follow up on the long-term preservation of the small-scale with roadside planters and how the performance is increasing with the time as the vegetation become fully-grown.

- Further research to investigate the effect of pontoon area and their effective size for increasing or decreasing drag force for amphibious houses.

- Research needs to be done in relation with the impact of socio-economic issues on flood preparation as well as the age of the population and regional variables.

- For the impact land usage patterns, it is important to continue the research of suitability analysis with multifunctional landscape and sustainable solutions.

- Further investigation is needed to demonstrate the need to respect watershed limits for lowland occupation.

- Flood forecasting review to make sure it is in accordance with a new safety level for flood prevention, flood control, and enhanced early warning systems.

\section{Conclusions}

Using as many measures capable of reducing the impacts of flooding as possible is part of an effective climate change adaptation strategy in urban development and improving storm water management in our cities, focusing on retaining, decelerating, discharging, and infiltrating rainfall in combination with pervious surfaces.

Large dams need to be re-evaluated for rehabilitation, as the use of the existing or new dams should be for the additional purpose of flood mitigation. In support of structural measures, the selection of the site for the flood dam should make room for the water away from urban areas.

Flood barriers and dikes are used to guard the zone from the stream. To reduce the criticality of dikes due to overflowing, it is necessary to increase its crest stature by almost triple that of the sea elevation, and a vegetation management plan is also an effective solution.

Cities need to convert active identification of flood response capacity, take action for appropriate scheme wide adjustment, and turn amphibious. Amphibious constructions are a valuable and diverse alternative solution of flood mitigation, since it can decrease the 
susceptibility to flood, and is an adaptation to allow for urban settlement and expansion in flood sectors.

Permeable pavement systems are operative for storm water management; the creation of a pervious system for the infiltration of rainwater with the use of geotextiles membranes decreases the contaminants from infiltrate run off into the ground.

Developing an early flood warning scheme to send early flood notice communications about possibly impacted zones will alleviate the adverse impacts of the flood occurrence, and the accurate performance of the flood forecasting system with proper maintenance of the flood warning system will reduce the impacts of flood damage.

Author Contributions: Conceptualization, S.A. and M.M.; methodology, M.M.; resources, M.M. and R.B.; writing-original draft preparation, M.M.; writing—review and editing, S.A. and R.B.; supervision, S.A. All authors have read and agreed to the published version of the manuscript.

Funding: This research received no external funding.

Data Availability Statement: Data is contained within the article.

Acknowledgments: The authors gratefully acknowledge the assistance of Andrea Bottacin Busolin from The University of Manchester, who reviewed and provided comments that greatly improved the manuscript.

Conflicts of Interest: The authors declare no conflict of interest.

\section{References}

1. Lemperiere, F. Dams and floods. Engineering 2017, 3, 144-149. [CrossRef]

2. Saintilan, N.; Khan, N.S.; Ashe, E.; Kelleway, J.J.; Kerrylee, R.; Colin, D.W.; Horton, B. Thresholds of mangrove survival under rapid sea level rise. Science 2020, 368, 1118-1121. [CrossRef] [PubMed]

3. O'Donnell, E.C.; Thorne, C. Drivers of future urban flood risk. Philos. Trans. R. Soc. A Math. Phys. Eng. Sci. 2020, $378,20190216$. [CrossRef] [PubMed]

4. Hawcroft, M.; Walsh, E.; Hodges, K.; Zappa, G.; Hawcroft, M.K. Significantly increased extreme precipitation expected in Europe and North America from extratropical cyclones. Environ. Res. Lett. 2018, 13, 124006. [CrossRef]

5. Catto, J.L.; Ackerley, D.; Booth, J.F.; Champion, A.J.; Colle, B.A.; Pfahl, S.; Pinto, J.G.; Quinting, J.F.; Seiler, C. The future of midlatitude cyclones. Curr. Clim. Chang. Rep. 2019, 5, 407-420. [CrossRef]

6. Stagl, J.; Mayr, E.; Koch, H.; Hattermann, F.F.; Huang, S. Effects of climate change on the hydrological cycle in Central and Eastern Europe. In Managing Protected Areas in Central and Eastern Europe under Climate Change; Springer: Berlin/Heidelberg, Germany, 2014; pp. 31-43.

7. Available online: https:/ / eciu.net/analysis/briefings/climate-impacts/flood-risk-and-the-uk (accessed on 18 December 2020).

8. Available online: https://yaleclimateconnections.org/2019/07/how-climate-change-is-making-hurricanes-more-dangerous / (accessed on 18 December 2020).

9. Available online: http://www.cgd.ucar.edu/staff/trenbert/trenberth.pdf/2018_Trenberth_et_al-Earths_Future.pdf (accessed on 18 December 2020).

10. Palom, A.R.; Olcina, J.; Sauri, D. More exposed but also more vulnerable? Climate change, high intensity precipitation events and flooding in Mediterranean Spain. Disaster Prev. Manag. Int. J. 2020. [CrossRef]

11. Available online: https://www.sciencemag.org/news/2017/03/flickr-tags-could-help-predict-floods (accessed on 18 December 2020).

12. Available online: https://www.usgs.gov / faqs/how-are-floods-predicted?qt-news_science_products=0\#qtnews_science_products (accessed on 18 December 2020).

13. Halgamuge, M.; Nirmalathas, A. Analysis of large flood events: Based on flood data during 1985-2016 in Australia and India. Int. J. Disaster Risk 2017, 24, 1-11. [CrossRef]

14. López-Marrero, T. An integrative approach to study and promote natural hazards adaptive capacity: A case study of two floodprone communities in Puerto Rico. Geogr. J. 2010, 176, 150-163. [CrossRef]

15. Bodoque, J.M.; Amérigo, M.; Díez-Herrero, A.; Garcia, J.A.; Cortés, B.; Ballesteros-Cánovas, J.A.; Olcina, J. Improvement of resilience of urban areas by integrating social perception in flash-flood risk management. J. Hydrol. 2016, 541, 665-676. [CrossRef]

16. Bodoque, J.; Díez-Herrero, A.; Amerigo, M.; García, J.; Olcina, J. Enhancing flash flood risk perception and awareness of mitigation actions through risk communication: A pre-post survey design. J. Hydrol. 2019, 568, 769-779. [CrossRef]

17. Tingsanchali, T. Urban flood disaster management. Procedia Eng. 2012, 32, 25-37. [CrossRef]

18. Dang, N.M.; Babel, M.S.; Luong, H.T. Evaluation of food risk parameters in the day river flood diversion area, Red River delta, Vietnam. Nat. Hazards 2011, 56, 169-194. [CrossRef]

19. Alkema, D.; Middelkoop, H. The influence of floodplain compartmentalization on flood risk within the Rhine-Meuse Delta. Nat. Hazards 2005, 36, 125-145. [CrossRef] 
20. Brammer, H. After the Bangladesh flood action plan: Looking to the future. Environ. Hazards 2010, 9, 118-130. [CrossRef]

21. Zhong, G.; Liu, S.; Hu, Z.; Zhang, X. Analysis of influence on region flood control due to polder waterlogging drainage in Yangcheng and Dianmao area. Yangtze River 2017, 48, 9-14.

22. Dawson, R.J.; Ball, T.; Werritty, J.; Werritty, A.; Hall, J.W.; Rpche, N. Assessing the effectiveness of non-structural flood management measures in the Thames Stuary under conditions of socio-ecnomic and environmental change. Glob. Environ. Chang. 2011, 21, 628-646. [CrossRef]

23. Orlovsky, A. Environmental impacts of levees and their mitigation. In Proceedings of the Aassociation of State Dam Safety Officials Annual Conference, Philadelphia, PA, USA, 11-14 September 2016.

24. Zelenakova, M.; Ondrejka Harbulakova, V.; Kovac, M.; Zvijakova, L. Earth fill dam as a flood mitigation measure in Andrejova. In Proceedings of the 15th International Multidisciplinary Scientific Geoconference and EXPO, SGEM 2015 V, Albena, Bulgaria, 18-24 June 2015; pp. 229-236.

25. Sörensen, J.; Persson, A.; Sternudd, C.; Aspegren, H.; Nilsson, J.; Nordström, J.; Jönsson, K.; Mottaghi, M.; Becker, P.; Pilesjö, P.; et al. Re-thinking urban flood management-time for a regime shift. Water 2016, 8, 332. [CrossRef]

26. Chang, H.-K.; Tan, Y.-C.; Lai, J.-S.; Pan, T.-Y.; Liu, T.-M.; Tung, C.-P. Improvement of a drainage system for flood management with assessment of the potential effects of climate change. Hydrol. Sci. J. 2013, 58, 1581-1597. [CrossRef]

27. Poussin, J.K.; Botzen, W.W.; Aerts, J.C. Effectiveness of flood damage mitigation measures: Empirical evidence from French flood disasters. Glob. Environ. Chang. 2015, 31, 74-84. [CrossRef]

28. ISDR U. UNISDR Terminology on Disaster Risk Reduction; ISDR U: Geneva, Switzerland, May 2009; Available online: https: //www.undrr.org/publication/2009-unisdr-terminology-disaster-risk-reduction (accessed on 18 December 2020).

29. Huang, Y.; Cheng, H. The impact of climate change on coastal geological disasters in southeastern China. Nat. Hazards 2013, 65, 377-390. [CrossRef]

30. Jayawardena, A. Hydro-meteorological disasters: Causes, effects and mitigation measures with special reference to early warning with data driven approaches of forecasting. In Proceedings of the 29th European Conference on Solid-State Transducers, Freiburg, Germany, 6-9 September 2015; pp. 3-12.

31. Imran, H.; Akib, S.; Karim, M.R. Permeable pavement and stormwater management systems: A review. Environ. Technol. 2013, 34, 2649-2656. [CrossRef] [PubMed]

32. Barros, M.T.L.; Conde, F.; Dunn, C.N.; Van Weele, B. Urban flood warning system social benefits. In Proceedings of the World environmental and Water Resources Congress 2017, Sacramento, CA, USA, 21-25 May 2017; pp. 642-653. [CrossRef]

33. Kreibich, H.; Bubeck, P.; Van Vliet, M.; De Moel, H. A review of damage-reducing measures to manage fluvial flood risks in a changing climate. Mitig. Adapt. Strat. Glob. Chang. 2015, 20, 967-989. [CrossRef]

34. Choi, H.; Lee, E.H.; Joo, J.G.; Kim, J. Determining optimal locations for rainwater storage sites with the goal of reducing urban inundation damage costs. KSCE J. Civ. Eng. 2016, 21, 2488-2500. [CrossRef]

35. Badenko, V.; Badenko, N.; Nikonorov, A.; Molodtsov, D.; Terleev, V.; Lednova, J.; Maslikov, V. Ecological aspect of dam design for flood regulation and sustainable urban development. In Proceedings of the 15th International Conference on Topical Problems of Architecture, Civil Engineering, Energy Efficiency and Ecology, Tyumen, Russia, 27-29 April 2016; Available online: https:/ / www.matecconferences.org/articles/matecconf/pdf/2016/36/matecconf_tpacee2016_03003.pdf (accessed on 18 December 2020).

36. Fedorov, M.; Badenko, V.; Maslikov, V.; Chusov, A. Site Selection for Flood Detention Basins with Minimum Environmental Impact. In Proceedings of the 15th International Scientific Conference Underground Urbanisation as a Prerequisite for Sustainable Development, St. Petersbug, Russia, 12-15 September 2016; pp. 1629-1636.

37. Posner, A.J.; Georgakakos, K.P. Quantifying the impact of community-scale flood mitigation. Int. J. Disaster Risk Reduct. 2017, 24, 189-208. [CrossRef]

38. Wieland, M. Safety aspects of sustainable storage dams and earthquake safety of existing dams. Engineering 2016, 2, 325-331. [CrossRef]

39. Heerten, G.; Werth, K. Mitigation of flooding by improved dams and dykes. Proc. Inst. Civ. Eng. Ground Improv. 2012, 165, 225-237. [CrossRef]

40. Takagi, H.; Fujii, D.; Esteban, M.; Yi, X. Effectiveness and limitation of coastal dykes in Jakarta: The need for prioritizing actions against land subsidence. Sustainability 2017, 9, 619. [CrossRef]

41. Chen, H.; Alani, A. Reliability and optimised maintenance for sea defences. Proc. Inst. Civ. Eng. Marit. Eng. 2012, 165, 51-63. [CrossRef]

42. Chen, H.-P. Maintenance of earth sea dykes in changing environmental and structural conditions. In Proceedings of the 4th International Symposium on Life-Cycle Civil Engineering, Tokyo, Japan, 16-19 November 2014; pp. 824-831.

43. Savatier, J.; Pépin, N.; Sénéchal, G.; Zanetti, C.; Liency, N.; Morellato, D.; Fourquet, L.; Saquet, J.P.; Jouathel, D.; Libourel, N.; et al. Toulose dykes: Reducing failure hazard combine structural reinforcement works and organization measures. In Proceedings of the 3rd European Conference on Flood Risk Management, Lyon, France, 17-21 October 2016. [CrossRef]

44. Rappazzo, D.; Aronica, G.T. Effectiveness and applicability of flood barriers fro risk mitigation in flash-flood prone Mediterranean area. In Proceedings of the 3rd European Conference on Flood Risk Management, Lyon, France, 17-21 October 2016. [CrossRef]

45. English, E.; Klink, N.; Turner, S. Thriving with water: Developments in amphibious architecture in North America. In Proceedings of the 3rd European conference on flood risk management Lyon, France, 17-21 October 2016. [CrossRef] 
46. English, E.C.; Friedland, C.J.; Orooji, F. Combined Flood and Wind Mitigation for Hurricane Damage Prevention: Case for Amphibious Construction. J. Struct. Eng. 2017, 143, 06017001. [CrossRef]

47. Mohamad, M.I.; Nekooie, M.A.; Bin Ismail, Z.; Taherkhani, R. Amphibious urbanization as a sustainable flood mitigation strategy in south-east Asia. Adv. Mater. Res. 2012, 622, 1696-1700. [CrossRef]

48. Nekooie, M.A.; Mohamad, M.I.; Ismail, Z. Drag Coefficient for Amphibious House. Urban Water J. 2017, 14, 1045-1057. [CrossRef]

49. Drake, J.; Bradford, A.; Marsalek, J. Review of environmental performance of permeable pavement systems: State of the knowledge. Water Qual. Res. J. 2013, 48, 203-222. [CrossRef]

50. Rodriguez-Rojas, M.; Fernández, F.H.; Moreno, B.; Martínez, G.; Grindlay, A.L. A study of the application of permeable pavements as a sustainable technique for the mitigation of soil sealing in cities: A case study in the south of Spain. J. Environ. Manag. 2018, 205, 151-162. [CrossRef] [PubMed]

51. Tota-Maharaj, K.; Scholz, M. Efficiency of permeable pavement systems for the removal of urban runoff pollutants under varying environmental conditions. Environ. Prog. Sustain. Energy 2010, 29, 358-369. [CrossRef]

52. Turco, M.; Kodešová, R.; Brunetti, G.; Nikodem, A.; Fér, M.; Piro, P. Unsaturated hydraulic behaviour of a permeable pavement: Laboratory investigation and numerical analysis by using the HYDRUS-2D model. J. Hydrol. 2017, 554, 780-791. [CrossRef]

53. Yang, W.-Y.; Li, D.; Sun, T.; Ni, G.-H. Saturation-excess and infiltration-excess runoff on green roofs. Ecol. Eng. 2015, 74, 327-336. [CrossRef]

54. Yuhong, W.; Huang, Y.; Rattanachot, W.; Lau, K.; Suwansawas, S. Improvement of pavement design and management for more frequent flooding caused by climate change. Adv. Struct. Eng. 2015, 18, 487-496.

55. Available online: https://www.eea.europa.eu/themes/water/interactive/by-category/floods-directive (accessed on 18 December 2020).

56. Liao, K.-H.; Le, T.A.; Van Nguyen, K. Urban design principles for flood resilience: Learning from the ecological wisdom of living with floods in the Vietnamese Mekong Delta. Landsc. Urban Plan. 2016, 155, 69-78. [CrossRef]

57. Ellis, C.; Cripps, R.; Russ, M.; Broom, S. Transforming water management in Llanelli, UK. Proc. Inst. Civ. Eng. Civ. Eng. 2016, 169, 25-33. [CrossRef]

58. Poussin, J.; Botzen, W.W.; Aerts, J. Factors of influence on flood damage mitigation behaviour by households. Environ. Sci. Policy 2014, 40, 69-77. [CrossRef]

59. Palencia, S. Resiliencia urbana ante inundaciones y temporales matitimos. J. Geophys. Res. Atmosphreres 2017, 121, $352-363$.

60. Ribas, A.; Pujol, D.S.; Cantos, J.O. Sustainable land use planning in areas exposed to flooding: Some international experiences. In Floods; Elsevier: Amsterdam, The Netherlands, 2017; pp. 103-117.

61. Miguez, M.G.; Veról, A.P.; De Sousa, M.M.; Rezende, O.M. Urban floods in lowlands-levee systems, unplanned urban growth and river restoration alternative: A Case Study in Brazil. Sustainability 2015, 7, 11068-11097. [CrossRef]

62. Wagner, M.; Merson, J.; Wentz, E. Design with nature: Key lesson from McHargs intrinsic suitablity in the wake of hurricane Sandy. Landsc. Urban Plan. 2016, 155, 33-46. [CrossRef]

63. Atreya, A.; Czajkowski, J.; Botzen, W.; Bustamante, G.; Campbell, K.; Collier, B.L.; Ianni, F.; Kunreuther, H.; Michel-Kerjan, E.O.; Montgomery, M. Adoption of flood preparedness actions: A household level study in rural communities in Tabasco, Mexico. Int. J. Disaster Risk Reduct. 2017, 24, 428-438. [CrossRef]

64. Ravazzani, G.; Amengual, A.; Ceppi, A.; Homar, V.; Romero, R.E.; Lombardi, G.; Mancini, M. Potentialities of ensemble strategies for flood forecasting over the Milano urban area. J. Hydrol. 2016, 539, 237-253. [CrossRef]

65. Gilbuena, R.; Kawamura, A.; Medina, R.R.; Amaguchi, H. Gap analysis of the flood management system in Metro Manila, Philippines: A case study of the aftermath of Typhoon Ondoy. In Proceedings of the 5th International Conference on Flood Management, Tokyo, Japan, 27-29 September 2011; Volume 357, pp. 32-40.

66. Hsu, M.-H.; Fu, J.-C.; Teng, W.-H. Applying river stage forecasting for early inundation warning. In Proceedings of the 7th International Conference on Fluvial Hydraulics, Lausanne, Switzerland, 3-5 September 2014; CRC Press/Balkema: Boca Raton, FL, USA, 2014; pp. 1767-1775.

67. Amengual, A.; Romero, R.; Gómez, M.; Martín, A.; Alonso, S. A hydrometeorological modeling study of a flash-flood event over Catalonia, Spain. J. Hydrometeorol. 2007, 8, 282-303. [CrossRef]

68. Headquarters IUCN. Making Disaster Risk Reduction Gender-Sensitive: Policy and Practical Guidelines; International Strategy for Disaster Reduction (ISDR); UNDP. Bureau for Crisis Prevention \& Recovery; IUCN Headquarters: Gland, Switzerland, 2009; Available online: http:/ / repo.floodalliance.net/jspui/bitstream/44111/1124/1/Making\%20Disaster\%20Risk\%20Reduction\% 20Gender\%20SensitivePolicy\%20and\%20Practical\%20Guidelines.pdf (accessed on 18 December 2020). 